Review

\title{
Microorganism remediation strategies towards heavy metals
}

\author{
Kun Yin ${ }^{\mathrm{a}}$, Qiaoning Wang ${ }^{\mathrm{a}, \mathrm{b}}$, Min $\mathrm{Lv}^{\mathrm{a}}$, Lingxin Chen ${ }^{\mathrm{a}, \mathrm{c}, *}$ \\ ${ }^{\text {a }}$ Laboratory of Coastal Environmental Processes and Ecological Remediation, Yantai Institute of Coastal Zone Research, Chinese Academy of Sciences, Yantai 264003, \\ China \\ ${ }^{\mathrm{b}}$ University of the Chinese Academy of Sciences, Beijing 100039, China \\ ${ }^{\mathrm{c}}$ School of Chemistry and Chemical Engineering, Yantai University, Yantai 264005, China
}

\section{H I G H L I G H T S}

- Heavy metal detoxification pathways of microorganisms have been summarized.

- Heavy metal remediation mechanisms of microorganisms have been included.

- Interactions between remediation mechanisms and detoxification pathways were discussed.

- The next-generation of bioremediation technologies has been put forward.

\section{A R T I C L E IN F O}

\section{Keywords:}

Heavy metal pollution

Microorganism remediation strategies

Detoxification pathways

Remediation mechanisms

\section{G R A P H I C A L A B S T R A C T}

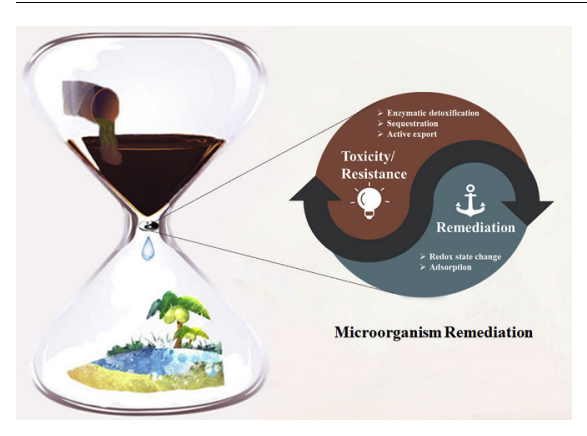

\begin{abstract}
A B S T R A C T
Heavy metal pollution, because of its high toxicity, non-biodegradability and biological enrichment, has seriously threatened the health of human beings and the stability of ecological system. The immobilization, removal and detoxification of active heavy metal ions in natural environment can be achieved through microbial activities. Because of its outstanding advantages including high efficiency, low cost and environment friendly, the development of high-efficiency biological techniques to clean up toxic metal wastes have already drawn scientists' great attention. After millions of years of evolution, some microorganisms are resistant to heavy metal ions and able to remediate heavy metal pollution. However, the relationship of microbial resistance system and their remediation ability towards heavy metal ions is still unclear. To uncover the underneath, we summarized heavy metal bioremediation technologies as well as their detoxification pathways in this review, which will contribute to find their interconnections and develop more efficient bioremediation technologies. Additionally, the future potential of gene-editing associated and advanced material associated multi-functional bioremediation technologies have been put forward in this review.
\end{abstract}

\section{Introduction}

Nowadays, heavy metal pollution caused by mining, steel production, and electroplating has induced an adverse impact on the environment, which threatens the health of human beings and the stability of ecosystem [1]. Heavy metal ions can be accumulated through food chain, which is believed to be a risk for human beings even at trace level [2]. Additionally, heavy metal ions can affect cellular organelles, components, and induce oxidative stress. For instance, arsenic can induce DNA hypomethylation and further facilitates aberrant

\footnotetext{
* Corresponding author at: Laboratory of Coastal Environmental Processes and Ecological Remediation, Yantai Institute of Coastal Zone Research, Chinese Academy of Sciences, Yantai 264003, China.

E-mail address: 1xchen@yic.ac.cn (L. Chen).
} 
gene expression [3]; chromium can induce DNA damage and oxidative stress in Sprague-Dawley rats and in human liver carcinoma cells [4]; copper has been reported to take part in the oncogenic BRAF signaling which is related to various cancers [5]. As a consequence, numerous diseases such as Menkes disease, Alzheimer's disease and cancers can be induced by the excessive intake of heavy metal ions [6]. Therefore, heavy metal pollution has already become one of the most serious environmental problems and the remediation of active heavy metal ions is of great importance.

Recently, a series of technologies such as chemical precipitation, ion-exchange and membrane filtration have been developed to remove heavy metal ions from polluted area, which focus on reducing metal bioavailability by transforming the heavy metal to the inactive state [7-9]. Among them, chemical precipitation method is simple, inexpensive and effective, which has become one of the most widely used methods for heavy metal treatment [7]. However, chemical precipitation method will generate low-density sludge and induce secondary pollution, which has many limitations and difficulties to clean up trace heavy metal pollution in large area. Ion-exchange resin for heavy metal treatment has high removal efficiency, high treatment capacity, and fast kinetics [8]. However, most ion-exchange techniques need to be used at acidic environment which limits their application. Membrane filtration technologies can remove heavy metal ions with high efficiency, but the production of membrane material is usually very complicated [10]. Traditional heavy metal remediation methods have many limitations including production of toxic chemical sludge and not eco-friendly. Therefore, simple and low-cost remediation method is urgently needed.

Nowadays, bioremediation technologies based on microorganisms have attracted scientists' great interest because of their outstanding advantages including high efficiency, low-cost and environmentfriendly, especially at low metal concentrations. Compared with plants and animals, microorganisms can resist environment stress through rapid mutation and evolution. Toxic heavy metal ions in active form influence the diversity and metabolic activity of microorganisms and in turn microorganisms can develop resistance systems to overcome the stress from toxic heavy metal ions. Additionally, some microorganisms can remediate heavy metal ions by transforming the active heavy metal ions into inactive forms, which can be used in the bioremediation of contaminated areas. However, the inner interrelationship between microbial resistance to heavy metal ions and their remediation ability is still unclear. Therefore, we have summarized the heavy metal remediation and their detoxification pathways of microorganisms to uncover the interrelationship, which will contribute to finding more efficient bioremediation strategies and developing the next-generation bioremediation technology.

\section{Heavy metal remediation strategies based on microorganisms}

Anthropogenic activities and natural processes are the main sources of heavy metal pollution. With rapid development of industry and agriculture production, anthropogenic sources, such as fossil fuel combustion, mining, corrosion, smelting and waste disposal, greatly contribute to heavy metal pollution [11-14]. Active heavy metal ions including cadmium, chromium, lead, platinum can be generated from electrolysis depositions, anodizing-cleaning, milling and etching industries [15-17]. Printed circuit board (PCB) manufacturing will bring forth heavy metal wastes such as lead, nickel and tin [18]. Chromium and cadmium pollution can be induced by inorganic pigment manufacturing and petroleum refining [19,20]. All these anthropogenic activities will generate heavy metal-polluted wastewaters, sludge, and residues, which influence the health of human beings.

Nowadays, numerous bioremediation technologies have been developed to remove heavy metal ions from polluted water, which offer valuable strategies for on-site remediation. Choosing suitable biomaterial is a major challenge for heavy metal bioremediation. At present, living/dead microorganisms and surface modified biomass are the most widely utilized strategies.

\subsection{Heavy metal remediation by living/dead microorganisms}

Heavy metal removal by living/dead microorganisms own outstanding advantages including simple-to-use, low cost, high adsorption capacity and large availability. Among these microorganisms, bacteria, fungi, and algae are most widely used (Table 1).

Table 1

Heavy metal removal by living microorganisms.

\begin{tabular}{|c|c|c|c|c|c|c|c|}
\hline \multicolumn{2}{|c|}{ Microorganism } & \multirow{2}{*}{$\begin{array}{l}\text { Target metals } \\
\mathrm{Hg}(\mathrm{II})\end{array}$} & \multirow{2}{*}{$\begin{array}{l}\text { Optimum pH } \\
7.0\end{array}$} & \multirow{2}{*}{$\begin{array}{l}\text { Isotherm model } \\
\text { Langmuir }\end{array}$} & \multirow{2}{*}{$\begin{array}{l}\text { Capacity }(\mathrm{mg} / \mathrm{g}) \\
180\end{array}$} & \multirow{2}{*}{$\begin{array}{l}\text { Regeneration } \\
\mathrm{Y}\end{array}$} & \multirow{2}{*}{$\begin{array}{l}\text { Reference } \\
{[21]}\end{array}$} \\
\hline Bacteria & Pseudomonas aeruginosa & & & & & & \\
\hline & Pseudomonas sp. & $\mathrm{Pb}(\mathrm{II})$ & 7.2 & Langmuir & 49.5 & $\mathrm{~N}$ & {$[22]$} \\
\hline & Bacillus sp. & $\mathrm{Pb}(\mathrm{II})$ & 5.0 & Langmuir, Freundlich & 15.4 & $\mathrm{~N}$ & [23] \\
\hline & Arthrobacter viscosus & $\mathrm{Cr}(\mathrm{VI})$ & 2.0 & Langmuir & 1161 & $\mathrm{~N}$ & {$[24]$} \\
\hline & Staphylococcus epidermidis & $\mathrm{Cr}(\mathrm{VI})$ & 5.0 & Freundlich & 56 & $\mathrm{~N}$ & {$[25]$} \\
\hline & Eichhornia spp. & $\mathrm{Cu}(\mathrm{II})$ & 5.0 & Langmuir & 28.5 & $\mathrm{~N}$ & [26] \\
\hline & Brevibacterium sp. & $\mathrm{Zn}(\mathrm{II})$ & 2.0 & Langmuir & 41.9 & $\mathrm{~N}$ & [27] \\
\hline & Rhodobacter capsulatus & $\mathrm{Zn}(\mathrm{II})$ & 7.0 & Langmuir, Redlich-Peterson & 164 & $\mathrm{~N}$ & [28] \\
\hline & Pseudomonaaeruginosa & Cd(II) & 6.0 & Langmuir, Freundlich & 16.9 & $\mathrm{~N}$ & [29] \\
\hline & Bacillus cereus & Cd(II) & 5.0 & Langmuir, Freundlich, Redlich-Peterson & 31.9 & $\mathrm{Y}$ & {$[30]$} \\
\hline & Ochrobactrum sp. & Cd(II) & 6.0 & Langmuir & 83.3 & $\mathrm{Y}$ & [31] \\
\hline \multirow[t]{8}{*}{ Fungi } & Aspergillus niger & $\mathrm{Pb}(\mathrm{II})$ & 5.4 & Langmuir & 172 & $\mathrm{~N}$ & {$[32]$} \\
\hline & Penicillium simplicissimum & $\mathrm{Pb}(\mathrm{II})$ & 5.0 & Langmuir & 76.9 & $\mathrm{~N}$ & [33] \\
\hline & Aspergillus fumigatus & $\mathrm{Cr}(\mathrm{VI})$ & 5.5 & Freundlich & 48.2 & $\mathrm{~N}$ & [34] \\
\hline & Termitomyces clypeatus & $\mathrm{Cr}(\mathrm{VI})$ & 2.0 & Langmuir, Freundlich & 403 & $\mathrm{~N}$ & [35] \\
\hline & Penicillium brevicompactum & $\mathrm{Co}(\mathrm{II})$ & 5.0 & Langmuir, Freundlich & 54.6 & $\mathrm{~N}$ & [36] \\
\hline & Saccharomyces cerevisiae & $\mathrm{Cu}(\mathrm{II})$ & 5.5 & Langmuir & 16 & $\mathrm{Y}$ & [37] \\
\hline & Trichoderma & Cd(II) & 6.0 & Langmuir, Freundlich & 21.7 & $\mathrm{~N}$ & [38] \\
\hline & Aspergillus niger & $\mathrm{Cd}(\mathrm{II})$ & 5.5 & Langmuir & 11 & $\mathrm{~N}$ & [39] \\
\hline \multirow[t]{7}{*}{ Algae } & Fucus vesiculosus & $\mathrm{Pb}(\mathrm{II})$ & 4.0 & Langmuir, Freundlich & 229 & $\mathrm{Y}$ & {$[40]$} \\
\hline & Cladophora fascicularis & $\mathrm{Pb}(\mathrm{II})$ & 5.0 & Langmuir, Freundlich & 198.5 & $\mathrm{~N}$ & [41] \\
\hline & Sargassum & $\mathrm{Cu}(\mathrm{II})$ & 5.0 & Langmuir & 49 & $\mathrm{~N}$ & [42] \\
\hline & Cystoseira crinitophylla & $\mathrm{Cu}(\mathrm{II})$ & 4.5 & Langmuir, Freundlich & 160 & $\mathrm{Y}$ & [43] \\
\hline & Spirogyra & $\mathrm{Cu}(\mathrm{II})$ & 5.0 & Langmuir, Freundlich & 87.2 & $\mathrm{~N}$ & [44] \\
\hline & Sargassum filipendula & Cd(II) & 6.0 & Langmuir & 7.8 & $\mathrm{Y}$ & [45] \\
\hline & Ulva lactuca & $\mathrm{Cr}(\mathrm{VI})$ & 1.0 & Langmuir, Freundlich, Redlich-Peterson, Koble-Corrigan & 10.6 & $\mathrm{~N}$ & {$[46]$} \\
\hline
\end{tabular}

Y: yes; N: not mentioned. 


\subsubsection{Bacteria}

Bacteria are the most abundant microorganisms in the earth, which can live in a wide range of environmental conditions. Because of their advantages such as small size, quick growth rate and easy to be cultivated, bacteria have been widely used to clean up heavy metal pollutants from the environment. As shown in Table 1, a series of heavy metal remediation methods based on bacteria including Escherichia, Pseudomonas, Bacillus and Micrococcus have been established. Generally, heavy metal ions can be adsorbed on the polysaccharide slime layers of bacteria through functional groups such as carboxyl, amino, phosphate and sulfate groups $[21,47,48]$. Heavy metal ions can bind on these groups and be accumulated with satisfactory adsorption capability. Generally, the uptake capacities of bacteria for heavy metal ions range from $1 \mathrm{mg} / \mathrm{g}$ to $500 \mathrm{mg} / \mathrm{g}$. Pseudomonas aeruginosa, as a type of mercury-resistant strain, can selectively adsorb mercury ion with a maximum uptake capacity of nearly $180 \mathrm{mg} / \mathrm{g}$ [21]. These mercury ions are accumulated by cysteine-rich transport proteins which are abundant in sulfhydryl groups and have high affinity to mercury ions. Pseudomonas sp. I3 and Bacillus sp. PZ-1 can adsorb Pb(II) from wastewater [22,23]. The dead and living Arthrobacter viscosus biomass can adsorb $\mathrm{Cr}(\mathrm{VI})$ with high adsorption capacity, satisfactory recovery efficiency and regeneration ability. Both living and dead cells can reduce $\mathrm{Cr}(\mathrm{VI})$ to $\mathrm{Cr}(\mathrm{III})$ in aqueous solution. When the initial concentrations of $\mathrm{Cr}(\mathrm{VI})$ is lower than $100 \mathrm{mg} / \mathrm{L}, 100 \% \mathrm{Cr}(\mathrm{VI})$ can be removed from aqueous solution under highly acidic $\mathrm{pH}(\mathrm{pH} 1$ and $\mathrm{pH}$ 2) [24]. The removal of $\mathrm{Cr}(\mathrm{VI})$ from aqueous solution by Staphylococcus epidermidis biofilms has been confirmed with high removal efficiency, which followed the Freundlich isotherm [25]. The Eichhornia spp. biomass collected from Chandola Lake can achieve $85.0 \%$ copper removal from 100 ppm Cu(II) containing solution [26]. The Zn(II) can be absorbed by bacterium Rhodobacter capsulatus with a maximal uptake capacity of $164 \mathrm{mg} / \mathrm{g}$, which followed the Redlich-Peterson and Langmuir isotherms [28]. Both the living and dead cells of bacteria Bacillus cereus RC-1 have the biosorption capacity for Cd(II), with about $24.01 \mathrm{mg} / \mathrm{g}$ and $31.95 \mathrm{mg} / \mathrm{g}$ for living and dead cells, respectively [30].

Besides, extracellular polymeric substances (EPS) constituted by nucleic acids, proteins, lipids and complex carbohydrates also play an important role in the adsorption of heavy metal ions. The EPS on the microbial cell surface can protect the microbes against heavy metal toxicity by avoiding their entrance into the intracellular environment. The presence of cationic and anionic functional groups on EPS can efficiently accumulate heavy metal ions including mercury, cobalt, copper and cadmium ions [49-51].

The adsorbed heavy metal ions can be transported into the living bacterial cells metabolism-dependently and redox state of heavy metal ions can be changed to reduce their toxicity. In our research group, Pseudomonas putida SP1 isolated from the marine environment is resistant to high-level mercury and other heavy metal ions. The isolated Pseudomonas putida SP1 can absorb almost $100 \%$ of total mercury and reduce reactive $\mathrm{Hg}$ (II) to $\mathrm{Hg}^{0}$ vapor by reductase, which realize the bioremediation of mercury pollution in marine environments [52]. Bacillus firmus TE7 is capable of reducing Cr(VI) and oxidizing As(III) simultaneously after accumulating them from wastewater [53]. The alteration of physicochemical conditions of heavy metal ions by reductase from the living microbes after binding by functional groups can reduce the toxicity of heavy metal ions, which will further enhance their remediation ability towards heavy metal pollutions.

\subsubsection{Fungi}

Fungi can live under high heavy metal concentration and accumulate both micronutrients and heavy metals. Therefore, fungi have been widely used to adsorb heavy metal ions and exhibit high metal uptake ability. The chitin-chitosan complex, glucuronic acid, phosphate and polysaccharides in/on cells of fungi play an important role in heavy metal adsorption through ion exchange and coordination [54]. Different types of ionizable sites and various functional groups including amine, carboxyl, hydroxyl, phosphate and sulfhydryl groups influence the adsorption capability and specificity of fungi strains to heavy metal ion. Aspergillus niger has been considered as suitable bio-sorbent to remove $\mathrm{Pb}(\mathrm{II})$ with high biosorption capacities [32]. The bio-removal of $\mathrm{Cr}(\mathrm{VI})$ by a native fungal isolate Aspergillus fumigatus from mine drainage has been studied. The maximum uptake of $48.2 \mathrm{mg} / \mathrm{g} \mathrm{Cr}(\mathrm{VI})$ can be achieved under optimized conditions, which followed the Freundlich isotherm [34]. The acidic surface of Termitomyces clypeatus biomass can absorb $\mathrm{Cr}(\mathrm{VI})$ with help of carboxyl, imidazole, phosphate, sulfhydryl, and hydroxyl functional groups [35]. The unmodified yeast cell biomass of Saccharomyces cerevisiae has been investigated to remove Cu(II) from wastewater [37]. Trichoderma has been used for the removal of Cd (II), which well fits Langmuir and Freundlich isotherm model [38]. Saccharomyces cerevisiae can remediate copper, zinc and cadmium pollution under high salt environment and the adsorption ability can be enhanced with the help of sodium chloride [55].

\subsubsection{Algae}

Algae, as a type of photosynthetic organisms, can grow in both freshwater and seawater. Nowadays, algae have been reported to have good capability to absorb heavy metal ions. Heavy metal ions can be accumulated by different peptides generated by algae, which can also protect algae from the toxicity of heavy metal ions [56]. Fucus vesiculosus has been reported to adsorb $\mathrm{Pb}(\mathrm{II})$ with high efficiency, which can be described by Langmuir and Freundlich equation [40]. The adsorption features of Cladophora fascicularis have been investigated for $\mathrm{Pb}(\mathrm{II})$ removal from wastewater, which followed the Langmuir and Freundlich isotherm models. The maximum adsorption capacity of Cladophora fascicularis to $\mathrm{Pb}$ (II) is $198.5 \mathrm{mg} / \mathrm{g}$ at $\mathrm{pH} 5.0$ and its biosorption kinetics followed the pseudo-second order model [41]. The free and immobilized marine algae Sargassum has been shown with good ability to clean up $\mathrm{Cu}$ (II) from aqueous solutions [42]. The copper biosorption by Cystoseira crinitophylla has been studied with very high adsorption capacity of $160 \mathrm{mg} / \mathrm{g}$ at $\mathrm{pH} 4.5$. The sorption isotherms well fit the Langmuir and Freundlich model and the Thomas and Clark models can be used to describe the heterogenous ion exchange [43]. Macro-algae Saccharina japonica and Sargassum fusiforme have been investigated with good removal capacities for $\mathrm{Cu}(\mathrm{II}), \mathrm{Cd}(\mathrm{II})$, and $\mathrm{Zn}(\mathrm{II})$ in aqueous solution [57]. The green microalga Desmodesmus sp. has been employed for the bioremediation of $\mathrm{Cu}(\mathrm{II})$ and $\mathrm{Ni}(\mathrm{II})$ from wastewater with high capacity [58].

\subsection{Heavy metal remediation by surface modified biomass}

Microorganisms include bacteria, fungi, yeasts and algal grow quickly and can produce high yields of biomass. Therefore, microorganism-based biomass can be easily and cheaply obtained, which is suitable to adsorb active heavy metal ion from the polluted area [59]. To achieve effective remediation of heavy metal ions, biomass is required to own high metal adsorption capacity. The natural biomass without being pretreated because of its low/medium adsorption capacities cannot meet the requirement as satisfactory adsorbents for heavy metal remediation. Therefore, various techniques including acid/alkalibased treatment and thermal treatment methods have been established to increase the adsorption capacity of the biomass (Fig. 1).

\subsubsection{Acid treatment}

Biomass treated by acid can open additional adsorption sites for heavy metals. After acid treatment, biomass is protonated and positive charge density is improved, which provides a strong electrostatic attraction between biomass and negatively charged heavy metal ions. Additionally, biomass can be chemically coated by acid on its surface after treatment, which introduces plenty of binding sites for cationic metals. For example, after modification by polyacrylic-acid, the uptake capacity of Cd(II) by Corynebacterium glutamicum biomass increased by 3.2 times compared with untreated biomass [60]. The acid-treated biomass of Trichoderma gamsii showed maximum biosorption capacity 




: OH, $\mathrm{NH}_{3}{ }^{+}, \mathrm{COOH}:$ Heavy metal ions

Fig. 1. Enhancing heavy metal removing efficiency of biomass through surface modification.

of $44.8 \mathrm{mg} / \mathrm{g}$, which followed pseudo-second-order model. The sorption isotherms for $\mathrm{Cr}(\mathrm{VI})$ by acid-treated Trichoderma gamsii followed Freundlich and Langmuir isotherm [61].

\subsubsection{Alkali treatment}

Biomass after alkali treatment can increase negative charge on biomass surface, which will enhance the electrostatic attraction for positive charged heavy metal ions. After alkali treatment, the uranium biosorption capacity of fungal mycelia is much higher than untreated groups [62]. Generally, sodium hydroxide, calcium hydroxide, sodium bicarbonate, and ammonium hydroxide are mostly utilized for alkali treatment. Compared with nature Mucor rouxii biomass, pretreatment with alkali chemicals such as $\mathrm{NaOH}, \mathrm{NaHCO}_{3}$, and $\mathrm{Na}_{2} \mathrm{CO}_{3}$ can improve its adsorption capacity [63].

\subsubsection{Thermal treatment}

Thermal treatment can make additional metal binding groups exposed which increase the concentration of surface functional groups. After thermal treatment under an inert atmosphere, the carbon hydrophobicity in biomass can be increased by removing hydrophilic surface functionalities. Additionally, thermal treatment can also increase the porosity and surface area of biomass, which will enhance the adsorption capacity of biomass. The thermal treated Saccharomyces cerevisiae can be utilized to remove $\mathrm{Cr}(\mathrm{VI})$ ions from wastewaters [64]. Similarly, autoclaving of bacterial biomass can also enhance the adsorption ability of heavy metal ions [65].

Physical treatments of Spirogyra biomasses including heating, autoclaving and chemical treatments (acetic acid and sodium hydroxide) can increase biosorption of selenium in comparison with live biomass [66].
Physical pretreatments such as heating, freeze drying, autoclaving and chemical treatments using acids and alkali can increase the Cd(II) biosorption capacity of Pleurotus florida biomass. Among physical treatments, significant improvement of Cd(II) biosorption capacity of Pleurotus florida biomass can be achieved by freeze drying and $\mathrm{NaOH}$-treated biomass show maximum cadmium biosorption among chemical treatments [67].

In conclusion, compared with surface modified biomass, active bioenzyme in living microorganisms contributes a lot to the detoxification of heavy metal ions through transforming them into low toxic forms but the binding sites and surface area are usually limited. Surface modified biomass can enhance the adsorption capacity of biomass through increasing binding sites, surface area and enhancing electrostatic attraction between biomass and heavy metal ions, but the bioenzyme is inactive after treatment which will inhibit the ability to transform high toxic heavy metal ions into low toxic forms. The comparison of heavy metal remediation strategies can be seen in Table 2.

\subsection{Heavy metal remediation by microorganisms at pilot/full-scale}

While many studies on the bioremediation of heavy metal are laboratory-based, there are some pilot/full-scale remediation technologies that have been established. The Arthrobacter viscosus biofilm has been verified that it can bind $\mathrm{Cr}(\mathrm{VI})$ in batch and column essays, which fits Freundlich model. A pilot bioreactor has been established after batch adsorption studies to clean up $\mathrm{Cr}(\mathrm{VI})$ from aqueous solutions with an average removal efficiency of $99.9 \%$ [68]. At 1995, Blowes and his coworkers first used sulfate-reducing bacteria to clean up heavy metal pollution in acid mine drainage at field scale [69]. Another full-scale sulfate-reducing bacteria (SRB) application on the remediation of heavy metal pollution has been achieved in Aznalcóllar (Spain), where $30 \mathrm{mg}$ / $\mathrm{L} \mathrm{Zn(II),} 30 \mathrm{mg} / \mathrm{L} \mathrm{Cu(II)}$ were contained in the wastewater [70]. A pilotscale biological reactor system based on bacterium Thauera selenatis has been established to remove Se(II) and $\mathrm{Ni}(\mathrm{II})$ in drainage water at the Panoche Water District, San Joaquin Valley, California [71]. All above confirm the great potential of using microorganisms in heavy metal remediation and they can be applied at pilot/full-scale.

\section{Resistance mechanisms of microorganisms to heavy metal ions}

Metal ions such as cobalt and copper ions play important roles in microorganisms for their participation in diverse metabolic processes as components of various enzymes [72]. But excessive uptake of these metal ions will bring serious risks to microorganisms such as damaging cell membranes, inhibiting enzyme activity, damaging DNA and disrupting cellular functions. Most heavy metal ions such as lead, silver, and mercury ions are potentially toxic to microorganisms with no nutrient value. However, many microorganisms show specific resistance to some heavy metal ions. The microbial resistance is particularly relevant to microbial ecology. Sensitive microbial strains could be reduced or disappear under heavy metal stress and will be replaced by strains which can better adapt to and tolerate the toxicity of heavy

Table 2

Comparison of heavy metal remediation strategies.

\begin{tabular}{|c|c|c|c|}
\hline Remediation strategies & Remediation mechanisms & Advantages & Disadvantages \\
\hline Living/dead microorganisms & $\begin{array}{l}1 \text {, Binding by functional } \\
\text { groups } \\
2 \text {, Redox state change }\end{array}$ & $\begin{array}{l}\text { 1, Simple-to-use, } \\
\text { 2, Low cost, } \\
\text { 3, Environmental friendly } \\
\text { 4, Can transform the valence of heavy metal ions into } \\
\text { low toxic forms }\end{array}$ & $\begin{array}{l}\text { Low/medium heavy metal adsorption capacity } \\
\text { (1, Insufficient binding sites } \\
2 \text {, Limited surface area } \\
3 \text {, Weak electrostatic attraction between biomass and } \\
\text { heavy metal ion) }\end{array}$ \\
\hline Surface modified biomass & Binding by functional groups & $\begin{array}{l}\text { High heavy metal adsorption capacity } \\
(1, \text { Plenty of binding sites, } \\
2 \text {, Enhanced electrostatic attraction between biomass } \\
\text { and heavy metal ion } \\
3 \text {, Bigger surface area) }\end{array}$ & $\begin{array}{l}\text { 1, Need modification } \\
\text { 2, Limited ability to transform the heavy metal ions } \\
\text { into low toxic forms }\end{array}$ \\
\hline
\end{tabular}




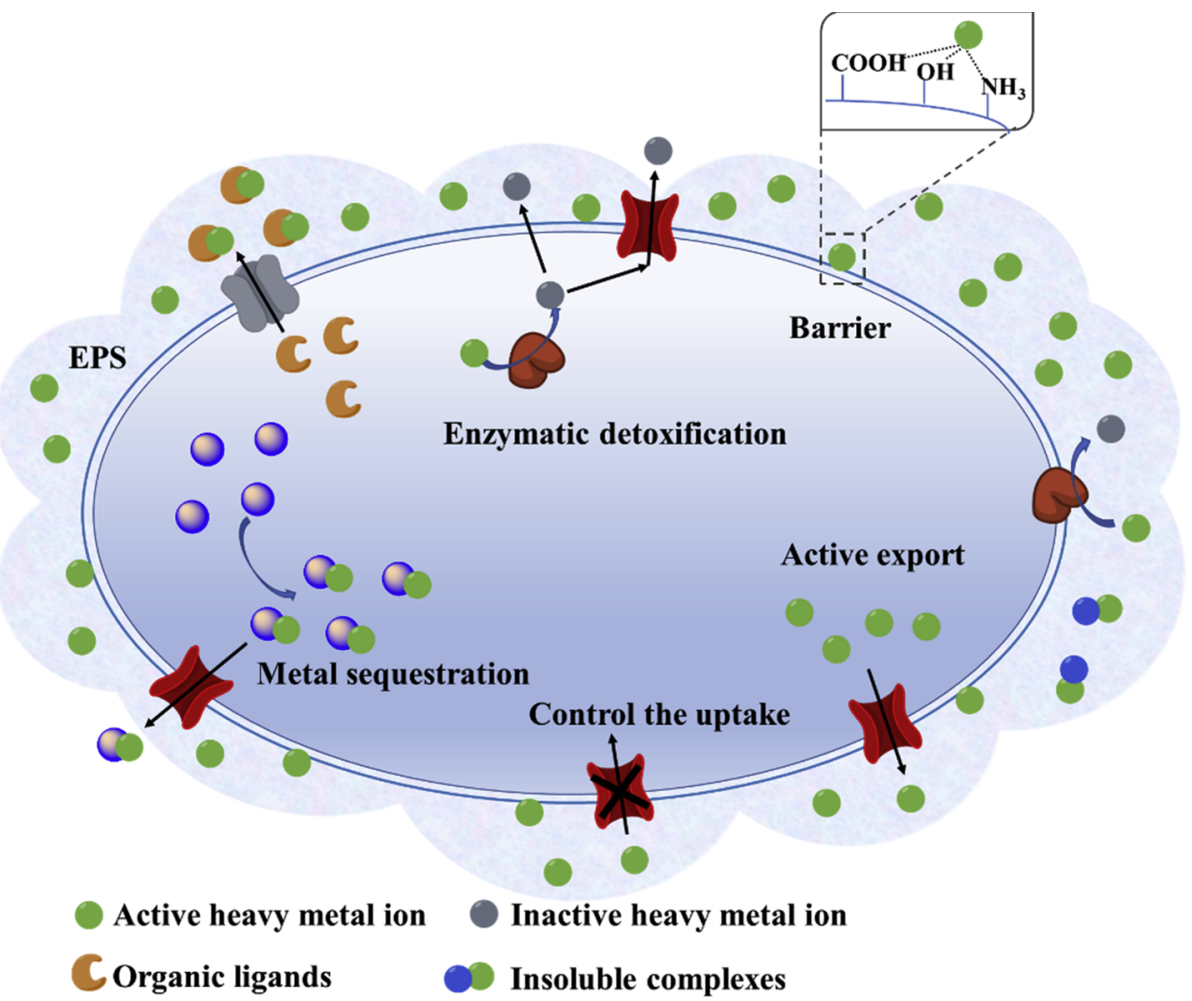

Fig. 2. Proposed detoxification pathways of microorganisms towards heavy metal ions [74-78].

Table 3

Resistance mechanisms of living microorganisms towards heavy metal ions.

\begin{tabular}{|c|c|c|c|c|}
\hline Resistance mechanisms & Resistance molecular & Heavy metal ions & Microorganisms & Reference \\
\hline \multirow[t]{6}{*}{ Extracellular sequestration } & \multirow[t]{3}{*}{ Extracellular polymeric substances } & $\mathrm{Cu}(\mathrm{II}), \mathrm{Cd}(\mathrm{II})$, and $\mathrm{Zn}(\mathrm{II})$ & Desulfovibrio desulfuricans & [47] \\
\hline & & $\mathrm{Cd}(\mathrm{II}), \mathrm{Pd}(\mathrm{II})$, and $\mathrm{Zn}(\mathrm{II})$ & Alteromonas macleodii & {$[82]$} \\
\hline & & $\mathrm{Cu}(\mathrm{II}), \mathrm{Pd}(\mathrm{II})$, and $\mathrm{Zn}(\mathrm{II})$ & Pseudomonas aeruginosa & [83] \\
\hline & \multirow[t]{2}{*}{ Siderophores } & Pd(II) & Ensifer adhaerens & [87] \\
\hline & & $\mathrm{Cr}(\mathrm{VI}), \mathrm{Pd}(\mathrm{II})$, and $\mathrm{Zn}(\mathrm{II})$ & Pseudomonas aeruginosa & {$[93]$} \\
\hline & Hydrogen sulfide & $\mathrm{Cd}(\mathrm{II}), \mathrm{Ni}(\mathrm{II})$, and $\mathrm{Cr}(\mathrm{VI})$ & Desulfovibrio desulfuricans & {$[90]$} \\
\hline \multirow[t]{3}{*}{ Intracellular sequestration } & \multirow[t]{2}{*}{ Polyphosphates } & $\mathrm{Cu}(\mathrm{II})$ & Sulfolobus solfataricus & [94] \\
\hline & & $\mathrm{Cd}(\mathrm{II})$ & Anacystis nidulans & [95] \\
\hline & Metallothionein & Cd(II), Zn(II) & Synechococcus $s p$ & [75] \\
\hline \multirow[t]{4}{*}{ Active export } & \multirow[t]{2}{*}{ P-type efflux ATPase } & $\mathrm{Cu}(\mathrm{II})$ & Sulfolobus solfataricus & [96] \\
\hline & & $\mathrm{Zn}(\mathrm{II})$ & Sinorhizobium meliloti & [97] \\
\hline & \multirow[t]{2}{*}{$\mathrm{ABC}$ transporters } & $\mathrm{Hg}(\mathrm{II}), \mathrm{Cd}(\mathrm{II})$, and $\mathrm{Zn}(\mathrm{II})$ & Escherichia coli & [98] \\
\hline & & $\mathrm{Au}(\mathrm{III})$ & Cupriavidus metallidurans & [99] \\
\hline \multirow[t]{3}{*}{ Enzymatic detoxification } & \multirow[t]{2}{*}{ Mercuric reductase } & $\mathrm{Hg}(\mathrm{II})$ & Pseudomonas sp. & {$[100]$} \\
\hline & & $\mathrm{Hg}(\mathrm{II})$ & Bacillus firmus & [101] \\
\hline & Catalase & As(III) & Acinetobacter sp. & [102] \\
\hline
\end{tabular}

metal ions. After many years of evolution, the microorganisms have physiological and chemical resistance mechanisms to overcome the toxicity of heavy metal ions [73]. Since microorganisms are the key factor in the bioremediation of heavy metals. The study of resistance mechanisms of microorganisms to heavy metal ions has a great contribution to the development of efficient bioremediation strategies. As shown in Fig. 2 and Table 3, the major detoxification pathways of heavy metal ions include extracellular sequestration, intracellular sequestration, active transport of the heavy metal and enzymatic detoxification, which can avoid heavy metal exposure or reduce their bioavailability.

\subsection{Extracellular sequestration}

Extracellular sequestration of active heavy metal ions can efficiently decrease their toxicity to microorganisms, which is the most widely used method for their removal. Heavy metal ions can be accumulated by various biological structures including extracellular polymeric substances, siderophores, glutathione and bio-surfactants. EPS constituted by nucleic acids, lipids, proteins, and complex carbohydrates, have abundant metal-binding sites such as carboxylic, hydroxyl, amino, sulphydryl and phosphate functional groups [74,79]. EPS are efficient bio-sorbents to various heavy metals including plumbum, copper, zinc, chromium and silver, which can influence the distribution of heavy metals in microorganisms [47,80-83]. Therefore, EPS can protect microorganisms against heavy metal toxicity and be utilized as an important bioremediation tool [50]. Siderophores like pyoverdine are organic ligands excreted by bacteria and fungi $[76,84,85]$. Siderophores have ability to accumulate ferric iron and form Fe-complexes, which help microorganisms survive under iron-deficient conditions. Beside ferric iron, siderophores can also bind other types of heavy metals including copper, zinc and nickel, which protect microorganisms from heavy metal toxicity [86-88]. Glutathione secreted by microorganisms 


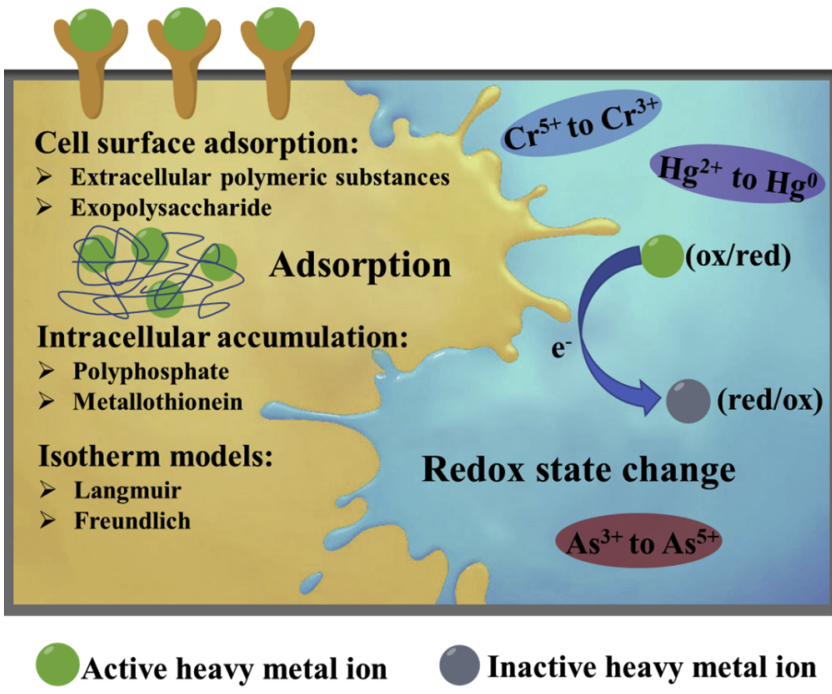

Fig. 3. Remediation mechanisms of microorganisms to heavy metal ions.

also has great ability to bind heavy metal ions. The heavy metal ions can be adsorbed with glutathione to form a complex and cannot enter living cells. The microbial production of hydrogen sulfide usually has significant effects on heavy metal detoxification. Desulfovibrio desulfuricans is unaffected by high concentrations of heavy metal ions with the help of hydrogen sulfide produced by itself. The secreted hydrogen sulfide in the extracellular environment will induce the precipitation of heavy metal ions and protect living cells from the toxicity of heavy metal ions [89-91]. Additionally, the cell wall of microorganisms is also a very important defense system against heavy metal toxicity. There are a great number of cationic and anionic functional groups on cell wall such as hydroxyl, amine, carboxyl and phosphate groups, which could avoid heavy metal ions entrancing into the intracellular environment by extracellular metal sequestration [92].

\subsection{Intracellular sequestration}

Once heavy metal ions cross cell wall and enter microorganisms, intracellular traps within the cytoplasm can sequestrate these heavy metal ions and prevent them from reaching toxic level. Therefore, sensitive cellular components can be protected from the exposure to heavy metal ions. Many microorganisms can transform heavy metal ions with the help of sulfides, cytosolic polyphosphates and cysteinerich proteins $[103,104]$. On one hand, the active heavy metal ions can be transformed to form insoluble metal precipitates. Some bacteria and cyanobacteria can utilize cytosolic polyphosphates to deposit heavy metal ions [94]. On the other hand, heavy metal ions can be accumulated by cysteine-rich proteins like metallothioneins. When exposed to heavy metal ions, metallothionein can be overexpressed to overcome this stress. Cysteine residues in metallothionein may act as a sink for excess toxic heavy metal ions. For example, Synechococcus sp. can secret metallothionein to bind $\mathrm{Cd}(\mathrm{II})$ and $\mathrm{Zn}(\mathrm{II})$ and reduce their toxicity to cells [105].

\subsection{Active export of heavy metal ions}

Transporting heavy metal ions away from the intracellular environment is another process to defend heavy metal stress, which can efficiently regulate intracellular concentrations of heavy metal ions with efflux systems [106]. These efflux systems have generally been found in different microorganisms, especially those isolated from metalpolluted environments. Generally, the expression of metal ion transporters in the efflux systems depends on bacterial species and heavy metal ions, which is regulated by special resistance genes on chromosome or plasmid. These genes encoded membrane transporters which control the uptake and exclusion of heavy metal ions. There are numerous metal exporting proteins widespread in the cell membrane to achieve the efflux of heavy metal ions such as P-type efflux ATPase, proton-cation anfiporters, $\mathrm{ABC}$ transporters and cation diffusion facilitator. The efflux of arsenite is regulated by an exporting protein on cell membrane with the help of ATPase [96,107]. Additionally, P-type efflux ATPase can help Gram-positive bacteria to export $\mathrm{Cu}(\mathrm{II}), \mathrm{Cd}(\mathrm{II})$, and Zn(II) [77]. ABC transporters (also called traffic ATPases) are able to mediate membrane translocation of heavy metal ions, which help microorganisms to overcome heavy metal stress $[98,99,108]$.

\subsection{Enzymatic detoxification}

The biotransformation or chemical modification of heavy metal ions from a high toxic form to a less harmful form by enzyme contributes a lot to the resistance of microorganisms to heavy metal ions [78]. The redox state change of heavy metal ions through reduction or oxidation reactions can efficiently decrease their toxicity [100]. This defense pathway can be regulated by detoxification enzymes, which is also controlled by special resistance genes of microorganisms. Bacteria like Bacillus sp. show resistance to mercury ions through mercuric ion reductase [101]. Mercuric reductase reduces mercuric ion to metallic mercury, which further is released to the surrounding environment through the cell membrane [52]. Bacteria Micrococcus sp. and Acinetobacter sp. can oxidize the toxic As(III) into less soluble and harmless $\mathrm{As}(\mathrm{V})$ to decrease its toxicity [102].

\section{Microorganism remediation mechanisms of heavy metal ions}

Bioremediation of heavy metal ions is to minimize their toxicity. On one hand, heavy metal ions can be captured by functional groups in/on microorganisms. On the other hand, some heavy metal ions can be transformed from a toxic form to a less harmful form through redox state change by microorganisms. As a result, the toxicity of heavy metal ions can be efficiently decreased (Fig. 3).

\subsection{Adsorption of heavy metal ions by functional groups}

Heavy metal adsorption of microorganism is usually achieved by electrostatic interaction or binding with active components including polysaccharides, chitin, and cellulose derivatives. Some heterogeneous compounds located in or exterior to cell walls can accumulate heavy metal ions effectively, which further enhance the survival of microorganism under environmental stress. The adsorption of heavy metal ions by exopolysaccharide is energy independent and non-metabolic, which is caused by electrostatic interaction between heavy metal cations and the negative charged functional groups of exopolysaccharides [109]. Accumulation of heavy metal ions is mainly achieved by functional groups on active components including carboxyl, amine, hydroxyl, sulfhydryl and phosphonate. For example, copper(II), lead(II) and chromium(IV) can be accumulated by the amino and carboxyl groups through displacement of protons, which can be confirmed by the modification/blocking of these groups $[110,111]$. Carboxyl groups in EPS have been reported to bind heavy metals and the blocking of carboxyl groups lead to the decrease of metal binding [47]. Amine can be positively charged after protonation and form negatively charged metal complexes. Amine group in polysaccharides and chitin components contribute a lot to the binding of heavy metals [78]. The phosphoryl groups are also the main binding sites for heavy metal ions [112]. Cd(II) and Co(II) can be stored in polyphosphate in C. humicola cells, which play an important role in heavy metal remediation [104]. The heavy metal adsorption has been suggested to be an ion exchange process by functional groups. The ionic state of carboxyl, amino and phosphate groups will promote reactions with the positively charged metal ions, which may be the reason that $\mathrm{pH}$ values usually greatly influence the 
adsorption capability of microorganisms towards heavy metal ions. Sulfhydryl compounds play an important role in heavy metal binding within cells. The Ksp of hydroxyl with $\mathrm{Hg}(\mathrm{II}), \mathrm{Cu}(\mathrm{II})$ and $\mathrm{Cd}(\mathrm{II})$ are $3.6 \times 10^{-26}, 2.2 \times 10^{-20}$ and $5.3 \times 10^{-15}$, respectively [113]. Compared with hydroxyl group, the Ksp of sulfhydryl group with $\mathrm{Hg}(\mathrm{II}), \mathrm{Cu}$ (II) and Cd(II) are $1.6 \times 10^{-52}, 6.3 \times 10^{-36}, 1.4 \times 10^{-29}$, respectively [114]. Therefore, the binding efficiency of sulfhydryl compounds to certain heavy metal ions are much higher than hydroxyl group. The metallothionein-like proteins, low molecular mass polypeptides with high cysteine content, show high binding ability to heavy metal ions, which protect microorganism from heavy metal toxicity. Significant correlation has been detected between mercury and sulfhydryl groups within the metallothioneins [115]. The binding ability of sulfhydryl compounds to heavy metal ions has also been investigated by atomic force microscope. All these indicate that the sulfhydryl content of microorganism plays important roles in the adsorption of heavy metal ions.

The biosorption of heavy metals by functional groups of microorganisms usually follows adsorption isotherm models. Generally, Langmuir and Freundlich models are the most widely used models to describe the heavy metal ions adsorption isotherm by microorganisms $[51,116,117]$. The classical Langmuir equation can be described as follow (1):

$\frac{C_{f}}{q}=\frac{C_{f}}{q_{\max }}+\frac{1}{b q_{\max }}$

$q$ means the metal uptake and $q_{\max }$ means the maximum adsorption capacity. $C_{f}$ means the final equilibrium solution concentration of mercury ion. $b$ means the ratio of adsorption/desorption rates. When no migration of adsorbate molecules occurs on the surface of microorganisms, the biosorption of heavy metals will follow the Langmuir model. The Freundlich equation can be described as follow (2):

$Q=K C_{e}^{1 / n}$

where $Q$ means the adsorbed amount of heavy metal ion by microorganisms, $K$ means adsorption equilibrium content indicative of adsorption capacity, $C_{e}$ means the equilibrium concentration and $\mathrm{n}$ means the adsorption intensity. The Freundlich model is usually applied if the microorganisms own heterogeneous surfaces. Besides Langmuir and Freundlich models, Brunauer-Emmett-Teller model is utilized when the adsorption of heavy metal ions by microorganisms occurs in multi-layer [118]. Additionally, Scatchard plots have also been used to describe the adsorption of heavy metal ions [119]. Even though sometimes the adsorption behavior of heavy metals cannot be explained by above isotherm models under complicated conditions, the information about metal-uptake capability can still be provided.

\subsection{Heavy metal remediation through redox state change}

The detoxification of heavy metal ions by changing their redox state to less harmful form by microorganisms has played an important role in the remediation of heavy metal pollution from the environment. Many kinds of microorganisms can catalyze such reactions utilizing metals ( $\mathrm{Fe}$ (III)) or metalloids $\left(\mathrm{S}^{0}\right)$ as terminal electron acceptors. The reduction of $\mathrm{Cr}(\mathrm{VI})$ to $\mathrm{Cr}(\mathrm{III})$ through enzymatic transformations has been widely studied in metal bioremediation by microorganisms. Insoluble hydroxides can be formed by reducing toxic $\mathrm{Cr}(\mathrm{VI})$ to $\mathrm{Cr}$ (III). SRB has been reported that its biofilms can reduce and precipitate $\mathrm{Cr}(\mathrm{VI})$ [120]. SRB based upflow anaerobic packed bed reactor has been developed to clean up $\mathrm{Cu}(\mathrm{II}), \mathrm{Ni}(\mathrm{II}), \mathrm{Zn}(\mathrm{II}), \mathrm{Al}(\mathrm{III}), \mathrm{Fe}(\mathrm{III})$, and $\mathrm{Mg}$ (II) from contaminated waters [121]. The heavy metal removal efficiencies of around $95 \%$ can be achieved by SRB for Ni(II), $\mathrm{Zn}(\mathrm{II}), \mathrm{Cr}(\mathrm{VI})$, and $\mathrm{Cu}(\mathrm{II})$ during the first 8 weeks with no inhibition of SRB growth [91]. The sulfide production, sulfate reduction and heavy metal precipitation with the help of SRB can efficiently remove heavy metals from polluted area. SRB can increase sulfide concentration through sulfate reduction, which further generate insoluble metal sulfides to inactivate heavy metal ions in the wastewater. As described before, the Ksp of sulfhydryl group with $\mathrm{Hg}$ (II), $\mathrm{Cu}(\mathrm{II})$ and $\mathrm{Cd}(\mathrm{II})$ are very low so that the generation of stable insoluble metal sulfides will greatly reduce the risk of heavy metals ion. The SRB can also work with copper-iron bimetallic particles to enhance heavy metal removal efficiency and anti-toxicity ability [122]. Bacillus amyloliquefaciens can utilize glucose for $\mathrm{Cr}(\mathrm{VI})$ reduction under aerobic conditions [123]. Additionally, microbial consortium can couple the oxidation of phenol to $\mathrm{Cr}(\mathrm{VI})$ reduction [124]. The detoxification of mercury by enzymatic transformation has also been well studied. The $\mathrm{Hg}$ (II) can be reduced by mercuric reductase such as merA to the less toxic and volatile $\mathrm{Hg}^{0}$ species [101,125]. For instance, Pseudomonas putida FB1 and Pseudomonas sp. B50A can reduce $\mathrm{Hg}$ (II) to $\mathrm{Hg}^{\mathrm{O}}$ with the help of merA reductase $[126,127]$. The engineered strains containing merA can increase mercury resistance and remediate mercury pollution to $\mathrm{Hg}^{0}$ [128]. Microbial transformations of arsenic have been reported for the remediation of arsenic pollution. Unlike other metal ions, the inorganic form of arsenic is more toxic than its methylated derivatives. Some microorganisms can methylate arsenic compounds and decrease its toxicity. Additionally, As(III) can be oxidized to $\mathrm{As}(\mathrm{V})$ and attenuate its toxicity. Chemical oxidation of As(III) is very slow under most environmental conditions but microorganisms can accelerate this process. For instance, As(III) can be oxidized much faster than abiotic processes with help of Thermus sp. [129]. Additionally, As(V) forms insoluble sulfides more readily than $\mathrm{As}(\mathrm{III})$ when exposed to $\mathrm{H}_{2} \mathrm{~S}$. Therefore, the oxidation of As(III) by microorganisms is a useful way of removing As from wastewater.

\section{Bottlenecks and future application}

Nowadays, heavy metal remediation by microorganisms has been utilized to remove heavy metal pollutions for its outstanding advantages of high-efficiency and low-cost. However, there are still many bottlenecks for its wide application. The molecular mechanism of heavy metal detoxification needs to be further elucidated to enhance the accumulation of heavy metal ions by microorganisms. The extracellular/ intracellular sequestration, active export and enzymatic detoxification are the main resistance mechanisms of living microorganisms to heavy metal ions, which will decrease the toxicity of heavy metal ions and transform them into inactive forms. The precipitation of heavy metal ions by hydrogen sulfide and redox state change of heavy metal ions by reductase increase the resistance of microorganisms to heavy metal ions and meanwhile achieve the heavy metal remediation. There is a close inner interrelationship between microbial resistance system to heavy metal ions and their remediation ability. Most studies use the spiked metal matrix to investigate the adsorption capability of microorganisms. However, the survival of microorganisms in the natural environment is usually different with spiked specimens under different environmental conditions, which will limit the on-site application [130]. Meanwhile, the effectiveness of the bioremediation processes can also be influenced by environmental factors such as $\mathrm{pH}$, temperature and ionic strength. For example, $\mathrm{pH}$ value influences the biosorption efficiency of heavy metal ions by changing the charge of functional groups on the cell surface and EPS [131]. Better remediation of heavy metal ions may be achieved by the combination of microorganisms with physical and chemical treatment, which can give microorganisms an optimized environment.

Considering the environmental conditions are quite complex, it is a big challenge to achieve the in-situ bioremediation of heavy metal ions. Generally, microorganisms can only resistant to special heavy metal ions. However, the microorganisms for the remediation of heavy metal ions in wastewater need to face the synergy toxicity of different heavy metal ions as well as cope with hydrological variations and complex contaminant mixtures. Additionally, some microorganisms which can remediate heavy metal pollution are conditional pathogenic and cannot 


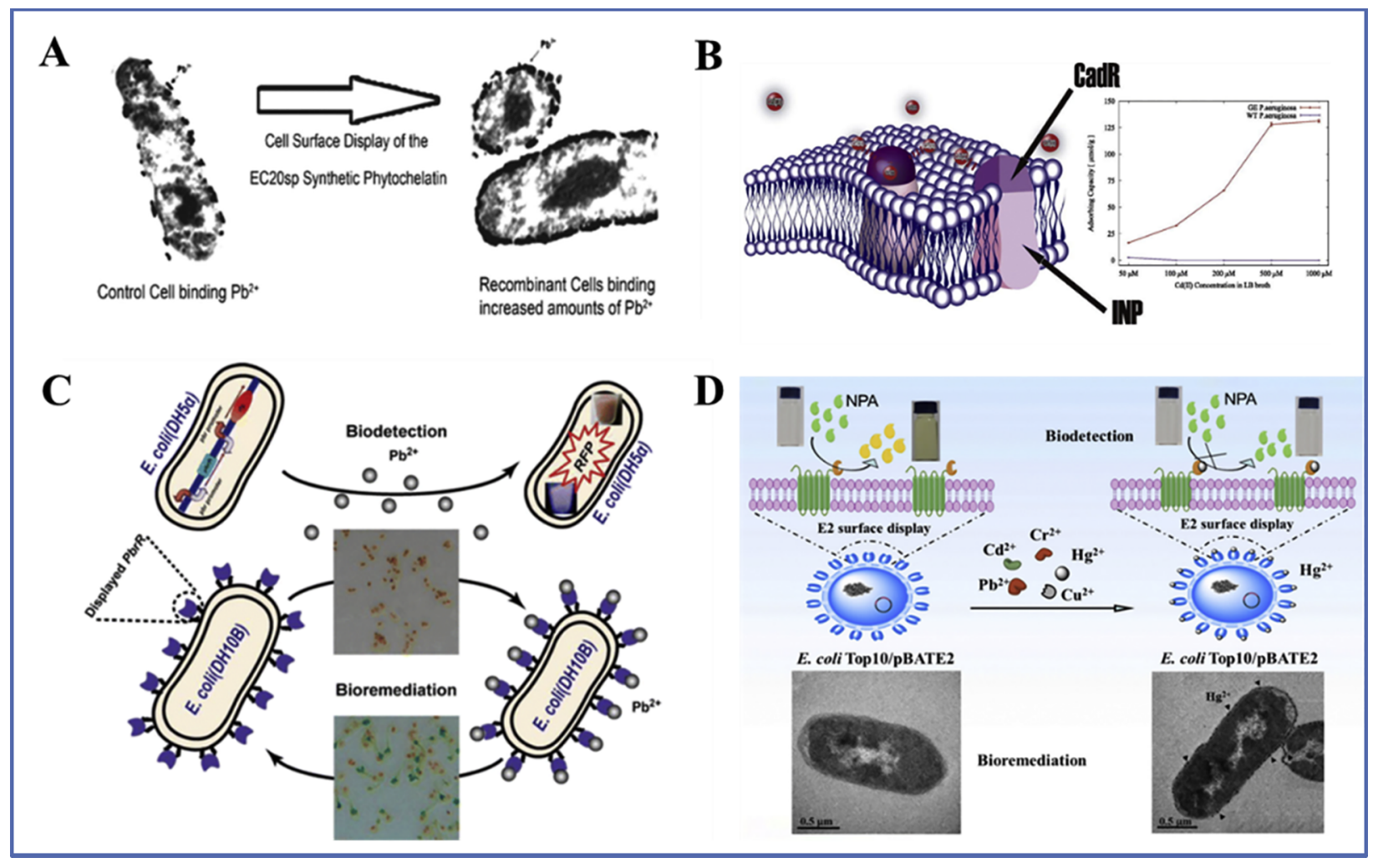

Fig. 4. Enhancing remediation efficiency of microorganisms to heavy metal ions through genetic engineering. A: phytochelatin surface display for enhanced metals bioremediation. Copyright 2018 American Chemical Society. B: expression of CadR on Pseudomonas aeruginosa for Cd(II) removal. Copyright 2018 Elsevier. C: heavy metals bioremediation by engineered lead-specific operon. Copyright 2014 American Chemical Society. D: bioremediation of mercury ion through surfacedisplay of carboxylesterase E2. Copyright 2016 Elsevier.

be widely used. To overcome these difficulties, genetic engineering is a good choice. Through overexpression of functional gene can increase the resistance of microorganisms to heavy metal ions. Multi-expression of different functional genes can help microorganisms overcome complex heavy metal toxicity. As shown in Fig. 4, the functional group can be located at more effective area through genetic engineering, which can also enhance the removal efficiency of heavy metal ions from the contaminated area [21,132-134]. The display of histidine oligopeptide on yeast can enhance their adsorption ability to heavy metal ions [135]. Through expressing Pyrus calleryana phytochelatin synthase, both the accumulation and resistance of heavy metal ions are enhanced for engineered E. coli bacteria [136].

Considering that genetic engineering can avoid the utilization of conditional pathogenic microorganisms as well as improve remediation efficiency by utilizing their functional gene, it has great potential in the future. Additionally, the combination of microorganisms with advanced material will also achieve high-efficient remediation of heavy metal ions, which need further investigation [137]. Due to the extremely low concentration of heavy metal ions in the environment, their quantification is also a major challenge. Therefore, the multifunctional microorganism system which can simultaneously realize remediation and detection of heavy metal pollution will also be the next consideration.

\section{Acknowledgements}

This work was financially supported by the National Natural Science Foundation of China (41601525, 21575159), the Natural Science Foundation of Shandong Province of China (ZR2016DB07), the Key research and development programs of Shandong Province of China (GG201709290055), and State Key Laboratory of Environmental Chemistry and Ecotoxicology, CAS, China (KF2017-11).

\section{References}

[1] A.S. Ayangbenro, O.O. Babalola, A new strategy for heavy metal polluted environments: a review of microbial biosorbents, Int. J. Environ. Res. Public Health 14 (2017) 94.

[2] X. Wang, C. Zhang, B. Qiu, U. Ashraf, R. Azad, J. Wu, S. Ali, Biotransfer of Cd along a soil-plant-mealybug-ladybird food chain: a comparison with host plants, Chemosphere 168 (2017) 699-706.

[3] P. Phookphan, P. Navasumrit, S. Waraprasit, J. Promvijit, K. Chaisatra, T. Ngaotepprutaram, M. Ruchirawat, Hypomethylation of inflammatory genes (COX2, EGR1, and SOCS3) and increased urinary 8-nitroguanine in arsenic-exposed newborns and children, Toxicol. Appl. Pharmacol. 316 (2017) 36-47.

[4] S. Terpilowska, A.K. Siwicki, Interactions between chromium (III) and iron (III), molybdenum (III) or nickel (II): cytotoxicity, genotoxicity and mutagenicity studies, Chemosphere 201 (2018) 780-789.

[5] M. Xu, M. Casio, D.E. Range, J.A. Sosa, C.M. Counter, Copper chelation as targeted therapy in a mouse model of oncogenic BRAF-driven papillary thyroid cancer, Clin. Cancer Res. (2018).

[6] J. Bornhorst, A.P. Kipp, H. Haase, S. Meyer, T. Schwerdtle, The crux of inept biomarkers for risks and benefits of trace elements, TrAC Trends Anal. Chem. (2017).

[7] A. Azimi, A. Azari, M. Rezakazemi, M. Ansarpour, Removal of heavy metals from industrial wastewaters: a review, ChemBioEng Rev. 4 (2017) 37-59.

[8] M.F.M.A. Zamri, M.A. Kamaruddin, M.S. Yusoff, H.A. Aziz, K.Y. Foo, Semi-aerobic stabilized landfill leachate treatment by ion exchange resin: isotherm and kinetic study, Appl. Water Sci. 7 (2017) 581-590.

[9] X. Fang, J. Li, X. Li, S. Pan, X. Zhang, X. Sun, J. Shen, W. Han, L. Wang, Internal pore decoration with polydopamine nanoparticle on polymeric ultrafiltration membrane for enhanced heavy metal removal, Chem. Eng. J. 314 (2017) 38-49.

[10] M. d'Halluin, J. Rull-Barrull, G. Bretel, C. Labrugère, E. Le Grognec, F.o.-X. Felpin, Chemically modified cellulose filter paper for heavy metal remediation in water, ACS Sustainable Chem. Eng. 5 (2017) 1965-1973.

[11] J.R. Martín, C. De Arana, J. Ramos-Miras, C. Gil, R. Boluda, Impact of 70 years urban growth associated with heavy metal pollution, Environ. Pollut. 196 (2015) $156-163$.

[12] S.C. Obiora, A. Chukwu, T.C. Davies, Heavy metals and health risk assessment of arable soils and food crops around $\mathrm{Pb}-\mathrm{Zn}$ mining localities in Enyigba, southeastern Nigeria, J. Afr. Earth Sci. 116 (2016) 182-189.

[13] S. Ganiyu, O. Olurin, K. Ajibodu, B. Badmus, A. Ajayi, Assessment of the degree of external corrosion of buried water pipelines and source identification of heavy metals due to surrounding soil conditions in humid environment, Environ. Earth 
Sci. 77 (2018) 443

[14] P. Li, C. Lin, H. Cheng, X. Duan, K. Lei, Contamination and health risks of soil heavy metals around a lead/zinc smelter in southwestern China, Ecotoxicol. Environ. Saf. 113 (2015) 391-399.

[15] S. Gunatilake, Methods of removing heavy metals from industrial wastewater, Methods 1 (2015).

[16] I. Anastopoulos, A. Bhatnagar, D.N. Bikiaris, G.Z. Kyzas, Chitin adsorbents for toxic metals: a review, Int. J. Mol. Sci. 18 (2017) 114.

[17] J. Liu, J. Wang, H. Li, C.C. Shen, Y. Chen, C. Wang, H. Ye, J. Long, G. Song, Y. Wu, Surface sediment contamination by uranium mining/milling activities in South China, Clean - Soil Air Water 43 (2015) 414-420.

[18] H.M. Veit, T.R. Diehl, A.P. Salami, J.d.S. Rodrigues, A.M. Bernardes, J.A.S. Tenório, Utilization of magnetic and electrostatic separation in the recycling of printed circuit boards scrap, Waste Manage. 25 (2005) 67-74.

[19] P.S. Parikh, S.K. Mazumder, Capacity of Azolla pinnata var. imbricata to absorb heavy metals and fluorides from the wastewater of oil and petroleum refining industry at Vadodara, Int. J. Allied Pract. Res. Rev. 2 (2015) 37-43.

[20] G. Wang, S. Wang, W. Sun, Z. Sun, S. Zheng, Synthesis of a novel illite@ carbon nanocomposite adsorbent for removal of Cr (VI) from wastewater, J. Environ. Sci. 57 (2017) 62-71.

[21] K. Yin, M. Lv, Q. Wang, Y. Wu, C. Liao, W. Zhang, L. Chen, Simultaneous bioremediation and biodetection of mercury ion through surface display of carboxylesterase E2 from Pseudomonas aeruginosa PA1, Water Res. 103 (2016) 383-390.

[22] D. Li, X. Xu, H. Yu, X. Han, Characterization of $\mathrm{Pb}^{2+}$ biosorption by psychrotrophic strain Pseudomonas sp. I3 isolated from permafrost soil of Mohe wetland in Northeast China, J. Environ. Manage. 196 (2017) 8-15.

[23] G. Ren, Y. Jin, C. Zhang, H. Gu, J. Qu, Characteristics of Bacillus sp. PZ-1 and its biosorption to Pb (II), Ecotoxicol. Environ. Saf. 117 (2015) 141-148.

[24] R.M. Hlihor, H. Figueiredo, T. Tavares, M. Gavrilescu, Biosorption potential of dead and living Arthrobacter viscosus biomass in the removal of $\mathrm{Cr}$ (VI): batch and column studies, Process Saf. Environ. Prot. 108 (2017) 44-56.

[25] K.G. Quiton, B. Doma Jr., C.M. Futalan, M.-W. Wan, Removal of chromium (VI) and zinc (II) from aqueous solution using kaolin-supported bacterial biofilms of Gram-negative E. coli and Gram-positive Staphylococcus epidermidis, Sustainable Environ. Res. (2018).

[26] S. Dave, M. Damani, D. Tipre, Copper remediation by Eichhornia spp. and sulphate-reducing bacteria, J. Hazard. Mater. 173 (2010) 231-235.

[27] J. Taniguchi, H. Hemmi, K. Tanahashi, N. Amano, T. Nakayama, T. Nishino, Zinc biosorption by a zinc-resistant bacterium, Brevibacterium sp. strain HZM-1, Appl. Microbiol. Biotechnol. 54 (2000) 581-588.

[28] J.-P. Magnin, N. Gondrexon, J.C. Willison, Zinc biosorption by the purple nonsulfur bacterium Rhodobacter capsulatus, Can. J. Microbiol. 60 (2014) 829-837.

[29] T. Limcharoensuk, N. Sooksawat, A. Sumarnrote, T. Awutpet, M. Kruatrachue, P. Pokethitiyook, C. Auesukaree, Bioaccumulation and biosorption of $\mathrm{Cd}^{2+}$ and $\mathrm{Zn}^{2+}$ by bacteria isolated from a zinc mine in Thailand, Ecotoxicol. Environ. Saf. 122 (2015) 322-330.

[30] F. Huang, Z. Dang, C.-L. Guo, G.-N. Lu, R.R. Gu, H.-J. Liu, H. Zhang, Biosorption of Cd (II) by live and dead cells of Bacillus cereus RC-1 isolated from cadmiumcontaminated soil, Colloids Surf. B: Biointerfaces 107 (2013) 11-18.

[31] E. Khadivinia, H. Sharafi, F. Hadi, H.S. Zahiri, S. Modiri, A. Tohidi, A. Mousavi, A.H. Salmanian, K.A. Noghabi, Cadmium biosorption by a glyphosate-degrading bacterium, a novel biosorbent isolated from pesticide-contaminated agricultural soils, J. Ind. Eng. Chem. 20 (2014) 4304-4310.

[32] S. Iram, S. Abrar, Biosorption of copper and lead by heavy metal resistant fungal isolates, Int. J. Sci. Res. Publ. 5 (2015) 1-5.

[33] T. Fan, Y. Liu, B. Feng, G. Zeng, C. Yang, M. Zhou, H. Zhou, Z. Tan, X. Wang, Biosorption of cadmium(II), zinc(II) and lead(II) by Penicillium simplicissimum: isotherms, kinetics and thermodynamics, J. Hazard. Mater. 160 (2008) 655-661.

[34] B. Dhal, B.D. Pandey, Mechanism elucidation and adsorbent characterization for removal of Cr (VI) by native fungal adsorbent, Sustainable Environ. Res. (2018).

[35] L. Ramrakhiani, R. Majumder, S. Khowala, Removal of hexavalent chromium by heat inactivated fungal biomass of Termitomyces clypeatus: surface characterization and mechanism of biosorption, Chem. Eng. J. 171 (2011) 1060-1068.

[36] K. Tsekova, M. Ianis, V. Dencheva, S. Ganeva, Biosorption of binary mixtures of copper and cobalt by Penicillium brevicompactum, Z. Naturforsch. C (2007) 261.

[37] S. Amirnia, M.B. Ray, A. Margaritis, Heavy metals removal from aqueous solutions using Saccharomyces cerevisiae in a novel continuous bioreactor-biosorption system, Chem. Eng. J. 264 (2015) 863-872.

[38] E. Bazrafshan, A.A. Zarei, F.K. Mostafapour, Biosorption of cadmium from aqueous solutions by Trichoderma fungus: kinetic, thermodynamic, and equilibrium study, Desalin. Water Treat. 57 (2016) 14598-14608.

[39] K. Tsekova, D. Todorova, V. Dencheva, S. Ganeva, Biosorption of copper(II) and cadmium(II) from aqueous solutions by free and immobilized biomass of Aspergillus niger, Bioresour. Technol. 101 (2010) 1727-1731.

[40] H. Demey, T. Vincent, E. Guibal, A novel algal-based sorbent for heavy metal removal, Chem. Eng. J. 332 (2018) 582-595.

[41] L. Deng, Y. Su, H. Su, X. Wang, X. Zhu, Sorption and desorption of lead (II) from wastewater by green algae Cladophora fascicularis, J. Hazard. Mater. 143 (2007) 220-225.

[42] C. Barquilha, E. Cossich, C. Tavares, E. Silva, Biosorption of nickel (II) and copper (II) ions in batch and fixed-bed columns by free and immobilized marine algae Sargassum sp. J. Cleaner Prod. 150 (2017) 58-64.

[43] A. Christoforidis, S. Orfanidis, S. Papageorgiou, A. Lazaridou, E. Favvas, A.C. Mitropoulos, Study of Cu (II) removal by Cystoseira crinitophylla biomass in batch and continuous flow biosorption, Chem. Eng. J. 277 (2015) 334-340.

[44] Y.-C. Lee, S.-P. Chang, The biosorption of heavy metals from aqueous solution by
Spirogyra and Cladophora filamentous macroalgae, Bioresour. Technol. 102 (2011) 5297-5304.

[45] S.L. Cardoso, C.S.D. Costa, E. Nishikawa, M.G.C. da Silva, M.G.A. Vieira, Biosorption of toxic metals using the alginate extraction residue from the brown algae Sargassum filipendula as a natural ion-exchanger, J. Cleaner Prod. 165 (2017) 491-499.

[46] A. El-Sikaily, A.E. Nemr, A. Khaled, O. Abdelwehab, Removal of toxic chromium from wastewater using green alga Ulva lactuca and its activated carbon, J. Hazard. Mater. 148 (2007) 216-228.

[47] Z.-B. Yue, Q. Li, C.-C. Li, T.-H. Chen, J. Wang, Component analysis and heavy metal adsorption ability of extracellular polymeric substances (EPS) from sulfate reducing bacteria, Bioresour. Technol. 194 (2015) 399-402.

[48] T.S. Anirudhan, S. Jalajamony, S.S. Sreekumari, Adsorption of heavy metal ions from aqueous solutions by amine and carboxylate functionalised bentonites, Appl. Clay Sci. 65-66 (2012) 67-71.

[49] L. Fang, Q. Huang, X. Wei, W. Liang, X. Rong, W. Chen, P. Cai, Microcalorimetric and potentiometric titration studies on the adsorption of copper by extracellular polymeric substances (EPS), minerals and their composites, Bioresour. Technol. 101 (2010) 5774-5779.

[50] G.-P. Sheng, J. Xu, H.-W. Luo, W.-W. Li, W.-H. Li, H.-O. Yu, Z. Xie, S.-Q. Wei, F.C. Hu, Thermodynamic analysis on the binding of heavy metals onto extracellular polymeric substances (EPS) of activated sludge, Water Res. 47 (2013) 607-614.

[51] J. Wang, Q. Li, M.-M. Li, T.-H. Chen, Y.-F. Zhou, Z.-B. Yue, Competitive adsorption of heavy metal by extracellular polymeric substances (EPS) extracted from sulfate reducing bacteria, Bioresour. Technol. 163 (2014) 374-376.

[52] W. Zhang, L. Chen, D. Liu, Characterization of a marine-isolated mercury-resistant Pseudomonas putida strain SP1 and its potential application in marine mercury reduction, Appl. Microbiol. Biotechnol. 93 (2012) 1305-1314.

[53] S.P. Bachate, V.S. Nandre, N.S. Ghatpande, K.M. Kodam, Simultaneous reduction of $\mathrm{Cr}(\mathrm{VI})$ and oxidation of As(III) by Bacillus firmus TE7 isolated from tannery effluent, Chemosphere 90 (2012) 2273-2278.

[54] D. Purchase, L.N. Scholes, D.M. Revitt, R.B.E. Shutes, Effects of temperature on metal tolerance and the accumulation of $\mathrm{Zn}$ and $\mathrm{Pb}$ by metal-tolerant fungi isolated from urban runoff treatment wetlands, J. Appl. Microbiol. 106 (2009) 1163-1174.

[55] C. Li, Y. Xu, J. Wei, X. Dong, D. Wang, B. Liu, Effect of $\mathrm{NaCl}$ on the heavy metal tolerance and bioaccumulation of Zygosaccharomyces rouxii and Saccharomyces cerevisiae, Bioresour. Technol. 143 (2013) 46-52.

[56] M. Bilal, T. Rasheed, J.E. Sosa-Hernández, A. Raza, F. Nabeel, H. Iqbal, Biosorption: an interplay between marine algae and potentially toxic elements - a review, Mar. Drugs 16 (2018) 65

[57] K.-M. Poo, E.-B. Son, J.-S. Chang, X. Ren, Y.-J. Choi, K.-J. Chae, Biochars derived from wasted marine macro-algae (Saccharina japonica and Sargassum fusiforme) and their potential for heavy metal removal in aqueous solution, J. Environ. Manage. 206 (2018) 364-372.

[58] L. Rugnini, G. Costa, R. Congestri, S. Antonaroli, L.S. di Toppi, L. Bruno, Phosphorus and metal removal combined with lipid production by the green microalga Desmodesmus sp.: an integrated approach, Plant Physiol. Biochem. 125 (2018) 45-51.

[59] M. Aryal, M. Liakopoulou-Kyriakides, Bioremoval of heavy metals by bacterial biomass, Environ. Monit. Assess. 187 (2015) 4173.

[60] J. Mao, S.W. Won, Y.-S. Yun, Development of poly (acrylic acid)-modified bacterial biomass as a high-performance biosorbent for removal of Cd (II) from aqueous solution, Ind. Eng. Chem. Res. 52 (2013) 6446-6452.

[61] B. Kavita, H. Keharia, Biosorption potential of Trichoderma gamsii biomass for removal of Cr (VI) from electroplating industrial effluent, Int. J. Chem. Eng. 2012 (2012).

[62] M.M. Khalil, R.A. Abou-Shanab, A.N.M. Salem, A.M. Omer, T.A. Aboelazm, Biosorption of trivalent chromium using Ca-alginate immobilized and alkalitreated biomass, J. Chem. Sci. Technol. (2016), https://doi.org/10.5963/ JCST0501001.

[63] G. Yan, T. Viraraghavan, Effect of pretreatment on the bioadsorption of heavy metals on Mucor rouxii, Water SA-Pretoria 26 (2000) 119-124.

[64] R. Hlihor, M. Diaconu, D. Fertu, C. Chelaru, I. Sandu, M. Gavrilescu, M. Tavares, Bioremediation of $\mathrm{Cr}$ (VI) polluted wastewaters by sorption on heat inactivated Saccharomyces cerevisiae biomass, Int. J. Environ. Res. 7 (2013) 681-694.

[65] M.L. Paul, J. Samuel, N. Chandrasekaran, A. Mukherjee, Comparative kinetics, equilibrium, thermodynamic and mechanistic studies on biosorption of hexavalent chromium by live and heat killed biomass of Acinetobacter junii VITSUKMW2, an indigenous chromite mine isolate, Chem. Eng. J. 187 (2012) 104-113.

[66] P. Mane, A. Bhosle, C. Jangam, C. Vishwakarma, Bioadsorption of selenium by pretreated algal biomass, Adv. Appl. Sci. Res. 2 (2011) 202-207.

[67] N. Das, D. Charumathi, R. Vimala, Effect of pretreatment on $\mathrm{Cd}^{2+}$ biosorption by mycelial biomass of Pleurotus florida, Afr. J. Biotechnol. 6 (2007).

[68] C. Quintelas, B. Fonseca, B. Silva, H. Figueiredo, T. Tavares, Treatment of chromium(VI) solutions in a pilot-scale bioreactor through a biofilm of Arthrobacter viscosus supported on GAC, Bioresour. Technol. 100 (2009) 220-226.

[69] D. Blowes, C. Ptacek, System for Treating Contaminated Groundwater, United States PATENT number 5,362,394, US Patent Office, 1995.

[70] J. Carrera, A. Alcolea, J. Bolzicco, C. Knudby, C. Ayora, An experimental geochemical barrier at Aznalcóllar, Proceedings of the 3rd International Conference on Groundwater Quality, 2001, pp. 18-21.

[71] A.W. Cantafio, K.D. Hagen, G.E. Lewis, T.L. Bledsoe, K.M. Nunan, J.M. Macy, Pilotscale selenium bioremediation of San Joaquin drainage water with Thauera selenatis, Appl. Environ. Microbiol. 62 (1996) 3298-3303.

[72] K. Yin, B. Li, X. Wang, W. Zhang, L. Chen, Ultrasensitive colorimetric detection of 
$\mathrm{Cu}^{2+}$ ion based on catalytic oxidation of 1-cysteine, Biosens. Bioelectron. 64 (2015) 81-87.

[73] M.J. Huertas, L. López-Maury, J. Giner-Lamia, A.M. Sánchez-Riego, F.J. Florencio, Metals in cyanobacteria: analysis of the copper, nickel, cobalt and arsenic homeostasis mechanisms, Life 4 (2014) 865-886.

[74] L. Wei, Y. Li, D.R. Noguera, N. Zhao, Y. Song, J. Ding, Q. Zhao, F. Cui, Adsorption of $\mathrm{Cu} 2+$ and $\mathrm{Zn} 2+$ by extracellular polymeric substances (EPS) in different sludges: effect of EPS fractional polarity on binding mechanism, J. Hazard. Mater. 321 (2017) 473-483.

[75] C. Blindauer, M. Harrison, J. Parkinson, N. Robinson, P. Sadler, Isostructural replacement of zinc by cadmium in bacterial metallothionein, Met. Ions Biol. Med. 10 (2008) 167-173.

[76] K.S. Chaturvedi, C.S. Hung, J.R. Crowley, A.E. Stapleton, J.P. Henderson, The siderophore yersiniabactin binds copper to protect pathogens during infection, Nat. Chem. Biol. 8 (2012) 731.

[77] G. Maynaud, B. Brunel, E. Yashiro, M. Mergeay, J.-C. Cleyet-Marel, A. Le Quéré, CadA of Mesorhizobium metallidurans isolated from a zinc-rich mining soil is a PIB-2-type ATPase involved in cadmium and zinc resistance, Res. Microbiol. 165 (2014) 175-189.

[78] S.-H. Liu, G.-M. Zeng, Q.-Y. Niu, Y. Liu, L. Zhou, L.-H. Jiang, X.-F. Tan, P. Xu, C. Zhang, M. Cheng, Bioremediation mechanisms of combined pollution of PAHs and heavy metals by bacteria and fungi: a mini review, Bioresour. Technol. 224 (2017) 25-33.

[79] Y. Shi, J. Huang, G. Zeng, Y. Gu, Y. Chen, Y. Hu, B. Tang, J. Zhou, Y. Yang, L. Shi, Exploiting extracellular polymeric substances (EPS) controlling strategies for performance enhancement of biological wastewater treatments: an overview, Chemosphere 180 (2017) 396-411.

[80] M. Deschatre, F. Ghillebaert, J. Guezennec, C.S. Colin, Sorption of copper(II) and silver(I) by four bacterial exopolysaccharides, Appl. Biochem. Biotechnol. 171 (2013) 1313-1327.

[81] P. Manivasagan, S.K. Kim, Extracellular polysaccharides produced by marine bacteria, Adv. Food Nutr. Res. 72 (2014) 79-94.

[82] M. Loaëc, R. Olier, J. Guezennec, Uptake of lead, cadmium and zinc by a novel bacterial exopolysaccharide, Water Res. 31 (1997) 1171-1179.

[83] G.M. Teitzel, M.R. Parsek, Heavy metal resistance of biofilm and planktonic Pseudomonas aeruginosa, Appl. Environ. Microbiol. 69 (2003) 2313-2320.

[84] K. Yin, Y. Wu, S. Wang, L. Chen, A sensitive fluorescent biosensor for the detection of copper ion inspired by biological recognition element pyoverdine, Sens. Actuators B: Chem. 232 (2016) 257-263.

[85] K. Yin, W. Zhang, L. Chen, Pyoverdine secreted by Pseudomonas aeruginosa as a biological recognition element for the fluorescent detection of furazolidone, Biosens. Bioelectron. 51 (2014) 90-96.

[86] P. Patel, S. Shaikh, R. Sayyed, Modified chrome azurol S method for detection and estimation of siderophores having affinity for metal ions other than iron, Environ. Sustainability (2018) 1-7.

[87] M. Oves, M.S. Khan, H.A. Qari, Ensifer adhaerens for heavy metal bioaccumulation, biosorption, and phosphate solubilization under metal stress condition, J. Taiwan Inst. Chem. Eng. 80 (2017) 540-552.

[88] R. Sharma, R. Bhardwaj, V. Gautam, S.K. Kohli, P. Kaur, R.S. Bali, P. Saini, A.K. Thukral, S. Arora, A.P. Vig, Microbial Siderophores in Metal Detoxification and Therapeutics: Recent Prospective and Applications, Plant Microbiome: Stress Response, Springer, 2018, pp. 337-350.

[89] G. Voordouw, The genus Desulfovibrio: the centennial, Appl. Environ. Microbiol. 61 (1995) 2813.

[90] J. ock Joo, J.-H. Choi, I.H. Kim, Y.-K. Kim, B.-K. Oh, Effective bioremediation of cadmium (II), nickel (II), and chromium (VI) in a marine environment by using Desulfovibrio desulfuricans, Biotechnol. Bioprocess Eng. 20 (2015) 937-941.

[91] H.T.Q. Kieu, E. Müller, H. Horn, Heavy metal removal in anaerobic semi-continuous stirred tank reactors by a consortium of sulfate-reducing bacteria, Water Res. 45 (2011) 3863-3870.

[92] M.M. Naik, S.K. Dubey, Lead resistant bacteria: Lead resistance mechanisms, their applications in lead bioremediation and biomonitoring, Ecotoxicol. Environ. Saf. 98 (2013) $1-7$

[93] A.A. Bhojiya, H. Joshi, Study of potential plant growth-promoting activities and heavy metal tolerance of Pseudomonas aeruginosa HMR16 isolated from Zawar Udaipur, India, Curr. Trends Biotechnol. Pharmacy 10 (2016) 161-168.

[94] F. Remonsellez, A. Orell, C.A. Jerez, Copper tolerance of the thermoacidophilic archaeon Sulfolobus metallicus: possible role of polyphosphate metabolism, Microbiology 152 (2006) 59-66.

[95] S. Keyhani, Intracellular polyphosphate content and cadmium tolerance in Anecystis nidulans R2, Microbios 88 (1996) 105-114.

[96] D.F. Soto, A. Recalde, A. Orell, S.-V. Albers, A. Paradela, C.A. Navarro, C.A. Jerez, Global effect of the lack of inorganic polyphosphate in the extremophilic archaeon Sulfolobus solfataricus: a proteomic approach, J. Proteomics (2018).

[97] M. Lu, Z. Li, J. Liang, Y. Wei, C. Rensing, G. Wei, Zinc resistance mechanisms of P1B-type ATPases in Sinorhizobium meliloti CCNWSX0020, Sci. Rep. 6 (2016) 29355.

[98] A. Lerebours, V.V. To, J.P. Bourdineaud, Danio rerio ABC transporter genes abcb3 and abcb7 play a protecting role against metal contamination, J. Appl. Toxicol. 36 (2016) 1551-1557.

[99] C.M. Zammit, F. Weiland, J. Brugger, B. Wade, L.J. Winderbaum, D.H. Nies, G. Southam, P. Hoffmann, F. Reith, Proteomic responses to gold (III)-toxicity in the bacterium Cupriavidus metallidurans CH34, Metallomics 8 (2016) 1204-1216.

[100] P. Giovanella, L. Cabral, F.M. Bento, C. Gianello, F.A.O. Camargo, Mercury (II) removal by resistant bacterial isolates and mercuric (II) reductase activity in a new strain of Pseudomonas sp. B50A, New Biotechnol. 33 (2016) 216-223.
[101] M. Noroozi, M. Amoozegar, A. Pourbabaei, N. Naghavi, Z. Nourmohammadi, Isolation and characterization of mercuric reductase by newly isolated halophilic bacterium, Bacillus firmus MN8, Global J. Environ. Sci. Manage. 3 (2017) $427-436$

[102] G.S. Nagvenkar, N. Ramaiah, Arsenite tolerance and biotransformation potential in estuarine bacteria, Ecotoxicology 19 (2010) 604-613.

[103] F. Li, W. Wang, C. Li, R. Zhu, F. Ge, Y. Zheng, Y. Tang, Self-mediated pH changes in culture medium affecting biosorption and biomineralization of $\mathrm{Cd}^{2+}$ by Bacillus cereus Cd01, J. Hazard. Mater. 358 (2018) 178-186.

[104] T. Kulakovskaya, L. Ryazanova, A. Zvonarev, G. Khokhlova, V. Ostroumov, M. Vainshtein, The biosorption of cadmium and cobalt and iron ions by yeast Cryptococcus humicola at nitrogen starvation, Folia Microbiol. (2018) 1-4.

[105] C.A. Blindauer, M.D. Harrison, J.A. Parkinson, N.J. Robinson, P.J. Sadler, Isostructural replacement of zinc by cadmium in bacterial metallothionein, Chemistry (2008).

[106] M. Remenar, A. Kamlarova, J. Harichova, M. Zámocký, P. Ferianc, The heavymetal resistance determinant of newly isolated bacterium from a nickel-contaminated soil in Southwest Slovakia, Pol. J. Microbiol. 67 (2018) 191-201.

[107] H.-C. Yang, H.-L. Fu, Y.-F. Lin, B.P. Rosen, Pathways of Arsenic Uptake and Efflux, Current Topics in Membranes, Elsevier, 2012, pp. 325-358.

[108] A.A. Al-Gheethi, J. Lalung, E.A. Noman, J. Bala, I. Norli, Removal of heavy metals and antibiotics from treated sewage effluent by bacteria, Clean Technol. Environ. Policy 17 (2015) 2101-2123.

[109] S.-Y. Kim, J.-H. Kim, C.-J. Kim, D.-K. Oh, Metal adsorption of the polysaccharide produced from Methylobacterium organophilum, Biotechnol. Lett. 18 (1996) 1161-1164.

[110] R. Dobrowolski, A. Szcześ, M. Czemierska, A. Jarosz-Wikołazka, Studies of cadmium (II), lead (II), nickel (II), cobalt (II) and chromium (VI) sorption on extracellular polymeric substances produced by Rhodococcus opacus and Rhodococcus rhodochrous, Bioresour. Technol. 225 (2017) 113-120.

[111] T. Wang, H. Sun, X. Ren, B. Li, H. Mao, Evaluation of biochars from different stock materials as carriers of bacterial strain for remediation of heavy metal-contaminated soil, Sci. Rep. 7 (2017) 12114.

[112] S. Schultze-Lam, M. Urrutia-Mera, T.J. Beveridge, Metal and Silicate Sorption and Subsequent Mineral Formation on Bacterial Surfaces: Subsurface Implications, Metal Contaminated Aquatic Sediments, Routledge, 2018, pp. 111-147.

[113] L. Liu, Y. Li, L. Zhan, Y. Liu, C. Huang, One-step synthesis of fluorescent hydroxylscoated carbon dots with hydrothermal reaction and its application to optical sensing of metal ions, Sci. China Chem. 54 (2011) 1342.

[114] Y. Sheng, H. Cao, Y. Li, Y. Zhang, Effects of sulfide on sulfate reducing bacteria in response to $\mathrm{Cu}$ (II), Hg (II) and Cr (VI) toxicity, Chin. Sci. Bull. 56 (2011) 862.

[115] M.M. Naik, S. Dubey, Lead-and Mercury-Resistant Marine Bacteria and their Application in Lead and Mercury Bioremediation, Marine Pollution and Microbial Remediation, Springer, 2017, pp. 29-40.

[116] M.N. Sahmoune, Performance of Streptomyces rimosus biomass in biosorption of heavy metals from aqueous solutions, Microchem. J. (2018).

[117] N.O. San Keskin, A. Celebioglu, O.F. Sarioglu, T. Uyar, T. Tekinay, Encapsulation of living bacteria in electrospun cyclodextrin ultrathin fibers for bioremediation of heavy metals and reactive dye from wastewater, Colloids Surf. B: Biointerfaces 161 (2018) 169-176.

[118] R.K. Gautam, P.K. Gautam, S. Banerjee, V. Rawat, S. Soni, S.K. Sharma, M.C. Chattopadhyaya, J. Environ. Chem. Eng. 2 (2014) 239-259.

[119] R. Black, M. Sartaj, A. Mohammadian, H.A. Qiblawey, Biosorption of Pb and $\mathrm{Cu}$ using fixed and suspended bacteria, J. Environ. Chem. Eng. 2 (2014) 1663-1671.

[120] X. Han, T.-X. Zhou, S.-W. Xu, Y. Li, Y.-F. Wang, Y. Liu, Removal of Cr (VI) and phenol coupled with the reduction of sulfate by sulfate-reducing bacteria sludge, Int. J. Environ. Sci. Technol. 14 (2017) 2173-2180.

[121] T. Jong, D.L. Parry, Removal of sulfate and heavy metals by sulfate reducing bacteria in short-term bench scale upflow anaerobic packed bed reactor runs, Water Res. 37 (2003) 3379-3389.

[122] Q. Zhou, Y. Chen, M. Yang, W. Li, L. Deng, Enhanced bioremediation of heavy metal from effluent by sulfate-reducing bacteria with copper-iron bimetallic particles support, Bioresour. Technol. 136 (2013) 413-417.

[123] S. Das, J. Mishra, S.K. Das, S. Pandey, D.S. Rao, A. Chakraborty, M. Sudarshan, N. Das, H. Thatoi, Investigation on mechanism of $\mathrm{Cr}(\mathrm{VI})$ reduction and removal by Bacillus amyloliquefaciens, a novel chromate tolerant bacterium isolated from chromite mine soil, Chemosphere 96 (2014) 112-121.

[124] R.N. Horton, W.A. Apel, V.S. Thompson, P.P. Sheridan, Low temperature reduction of hexavalent chromium by a microbial enrichment consortium and a novel strain of Arthrobacter aurescens, BMC Microbiol. 6 (2006) 1-8.

[125] A.K. Møller, T. Barkay, M.A. Hansen, A. Norman, L.H. Hansen, S.J. Sørensen, E.S. Boyd, N. Kroer, Mercuric reductase genes (merA) and mercury resistance plasmids in high Arctic snow, freshwater and sea-ice brine, FEMS Microbiol. Ecol. 87 (2014) 52-63.

[126] D. Battistel, F. Baldi, D. Marchetto, M. Gallo, S. Daniele, A rapid electrochemica procedure for the detection of $\mathrm{Hg}(0)$ produced by mercuric-reductase: application for monitoring Hg-resistant bacteria activity, Environ. Sci. Technol. 46 (2012) 10675-10681.

[127] P. Giovanella, L. Cabral, F. Bento, C. Gianello, F.A. Camargo, Mercury (II) removal by resistant bacterial isolates and mercuric (II) reductase activity in a new strain of Pseudomonas sp. B50A, New Biotechnol. 33 (2016) 216-223.

[128] N.R.D. Jaysankar, L. Vardanyan, De Jaysankar, N. Ramaiah, L. Vardanyan, Detoxification of toxic heavy metals by marine bacteria highly resistant to mercury, Mar. Biotechnol. 10 (4) (2008) 471-477.

[129] T.M. Gihring, J.F. Banfield, Arsenite oxidation and arsenate respiration by a new Thermus isolate, FEMS Microbiol. Lett. 204 (2001) 335-340. 
[130] K. Hrynkiewicz, C. Baum, Selection of ectomycorrhizal willow genotype in phytoextraction of heavy metals, Environ. Technol. 34 (2013) 225-230.

[131] S.F. Lo, S.Y. Wang, M.J. Tsai, L.D. Lin, Adsorption capacity and removal efficiency of heavy metal ions by Moso and Ma bamboo activated carbons, Chem. Eng. Res. Des. 90 (2012) 1397-1406.

[132] R. Biondo, F.A. da Silva, E.J. Vicente, J.E. Souza Sarkis, A.C.G. Schenberg, Synthetic phytochelatin surface display in Cupriavidus metallidurans CH34 for enhanced metals bioremediation, Environ. Sci. Technol. 46 (2012) 8325-8332.

[133] X. Tang, G. Zeng, C. Fan, M. Zhou, L. Tang, J. Zhu, J. Wan, D. Huang, M. Chen, P. Xu, Chromosomal expression of CadR on Pseudomonas aeruginosa for the removal of Cd (II) from aqueous solutions, Sci. Total Environ. 636 (2018) 1355-1361.

[134] W. Wei, X. Liu, P. Sun, X. Wang, H. Zhu, M. Hong, Z.-W. Mao, J. Zhao, Simple whole-cell biodetection and bioremediation of heavy metals based on an engineered lead-specific operon, Environ. Sci. Technol. 48 (2014) 3363-3371.

[135] K. Kuroda, S. Shibasaki, M. Ueda, A. Tanaka, Cell surface-engineered yeast displaying a histidine oligopeptide (hexa-His) has enhanced adsorption of and tolerance to heavy metal ions, Appl. Microbiol. Biotechnol. 57 (2001) 697-701.

[136] H. Li, Y. Cong, J. Lin, Y. Chang, Enhanced tolerance and accumulation of heavy metal ions by engineered Escherichia coli expressing Pyrus calleryana phytochelatin synthase, J. Basic Microbiol. 55 (2015) 398-405.

[137] S. Xin, Z. Zeng, X. Zhou, W. Luo, X. Shi, O. Wang, H. Deng, Y. Du, Recyclable Saccharomyces cerevisiae loaded nanofibrous mats with sandwich structure constructing via bio-electrospraying for heavy metal removal, J. Hazard. Mater. 324 (2017) 365-372. 